\title{
Electrophysical agents (EPAs) for symptom control in cancer care - what is the evidence?
}

\section{E-Liisa Laakso, Catherine Young}

School of Physiotherapy and Exercise Science and Griffith Health Institute, Griffith University, Gold Coast, Queensland, Australia

Background: Physiotherapists generally accept that electrophysical agents (EPAs) should not be applied directly over, or in the vicinity of cancerous tumours or other malignancies. The idea that EPAs are contraindicated is based upon the theoretical, but rarely proven risk of stimulating malignant cell proliferation and thus tumour growth and/or dissemination. However, a growing body of literature suggests that some electromagnetic and physical energies may be beneficial for use in the treatment of cancerrelated or cancer treatment-related sequelae, and tumours.

Objectives: The aim of this narrative review was to collate information on the state of knowledge regarding the application of EPAs in some typical clinical presentations in physiotherapy cancer care; understand whether there is evidence for using EPAs in physiotherapy cancer care; and, how planning might progress to further the evidence in this field.

Major findings: Few EPAs have been specifically tested for the capacity to increase tumour growth or dissemination. Evidence exists for the use of some EPAs for symptom control and palliative management of cancer-related or cancer treatment-related symptoms and side effects.

Conclusions: Physiotherapists should reconsider the potential use of EPAs in cancer care. Further research will elucidate how best to utilize EPAs in this field of practice. Using some EPAs for tumour treatment could be considered.

Keywords: Physiotherapy, Electrophysical agents, Cancer care, Contraindications

\section{Background}

The most common treatment for patients diagnosed with cancer is some combination of surgery, chemotherapy and radiation therapy. Physiotherapists play a supportive role in cancer management, offering preventive care, functional rehabilitation and symptom control. Electrophysical agents (EPAs), such as transcutaneous electrical nerve stimulation (TENS), therapeutic ultrasound (US), and low level laser therapy (LLLT) are used by physiotherapists to reduce pain of musculoskeletal origin, to facilitate tissue healing and promote functional rehabilitation but rarely in cancer care. A number of professional organizations have developed guidelines regarding the clinical use of EPAs, e.g. ${ }^{1,2}$ Typically, the list of recommended contraindications includes the application of electromagnetic energies directly over, or in the vicinity of tumour, or whenever a malignant condition is present. Breaches of this contraindication have the theoretical potential to result in the stimulation of malignant cell proliferation, and

Correspondence to: Liisa Laakso, School of Physiotherapy and Exercise Science, Griffith University, Gold Coast, Queensland 4222, Australia. Email: I.laakso@griffith.edu.au thus tumour growth and/or spread. Other inadvertent outcomes include the potential to alter local concentrations of drugs, and unpredictable local reactions to the EPA due to altered cellular metabolism. Traditionally, emphasis on this contraindication has caused it to become a 'blanket rule' in physiotherapy, which results in constriction of clinical reasoning in situations where a particular EPA could provide the same beneficial physical outcomes in patients with cancer as occur in those with musculoskeletal conditions. The dilemma is to know whether, in the absence of specific evidence to the contrary, it is reasonable to apply an EPA in the presence of malignancy. Before the efficacy of EPAs can be determined, the safety of each EPA for specific types of disease, at particular stages, must first be established.

The notion that an EPA could be safe, and appropriately applied for symptom control in cancer patients should not be tested using clinical randomized control trial (RCT) methodologies. A more suitable paradigm is the one currently used by pharmaceutical companies when testing new cancer chemotherapies or pharmacological agents. That is, a continuum that includes preclinical studies of the 
effects of energies (in cell cultures to identify efficacy and in animal models to evaluate efficacy, toxicity, and safety); further testing in phase 0 (microdosing) clinical studies; small cohort phase 1 (dose-ranging) studies; then larger cohort phase 2 RCT (which could be used for identifying dose-response characteristics); and phase 3 multicentre trials. In the case of testing the safety and efficacy of EPAs for symptom control in malignancy, it would be imperative to also formulate phase 4 studies that included safety surveillance once the EPA was in common usage. Phase 4 studies are designed to detect unusual adverse effects of the EPA in the proposed application. Physiotherapists should be leading such research and formulating the research questions.

In order to understand the breadth and depth of evidence regarding the safety and efficacy of EPAs in the field of cancer care the authors searched the Scopus, MEDline, Scirus, and Cinahl databases, and the internet, for publications describing clinical applications of EPAs for the relief of signs and symptoms related to cancer. The literature includes a significant number of publications relevant to the use of EPAs in cancer care; however, the scope of this paper has been limited to the control of major symptoms or side effects of cancer and its treatment. In particular, cancer-related (malignant) pain, neuromotor control issues, chemotherapy-induced nausea, breast cancer-related lymphoedema (BCRL), and radiation/chemotherapy-induced oral mucositis. We included studies relating to both the curative and palliative management approaches. A brief discussion of the possible use of EPAs as primary cancer treatment is also included. Based on available evidence, in the following sections the authors have attempted to draw conclusions regarding the safety of EPAs in cancer settings; and provide recommendations for where further research might best be targeted.

\section{Cancer Pain}

In its early stages malignant pain can masquerade as a common musculoskeletal condition (e.g., brain tumours may initially present as headache of cervicogenic origin). Cancer related pain differs from symptoms of musculoskeletal origin in that it is often intractable and unremitting, responding poorly to simple analgesics. Cancer pain has an insidious onset and is typically worst at rest or at night. It is most often caused by: direct compression on or traction by tumour of innervated structures (e.g., solid tumours in confined spaces such as the cranial cavity) or nerve fibres; destruction of structural integrity of tissue (e.g., bony metastases resulting in pathological fractures); or rarely, through neural infiltration. Although subject to recent criticism, cancer pain should be treated according to the World Health Organization (WHO) guidelines using the analgesic ladder. $^{3}$ Electrophysical agents may complement pharmacological agents.

\section{Superficial warming and cooling}

Generally, superficial physical agents such as heat packs for warming or ice packs for cooling are considered to be the safest, non-pharmacological options for the management of malignant pain that is unresponsive to medication, regardless of the stage of cancer. Despite a theoretical risk of disseminating malignant cells by altering local metabolism ${ }^{4}$ the effect of warming or cooling tissues with malignancy has not been specifically tested (e.g., the effect of warming on a superficial malignant melanoma). As such, the full continuum of research starting with preclinical animal trials may be appropriate for these applications. Empirical evidence suggests that warming and cooling modalities offer only brief symptomatic effects that are not sustained beyond the period of the application. Such transient pain modulation is not unexpected given the likely mechanisms of effect of superficial warmth and cooling, and the pathophysiological basis of malignant pain. However, either agent can be beneficial when optimal pharmacological pain control is still to be achieved. Applications of warm or cool packs can provide patients with some additional control over symptoms.

\section{Electrical stimulation}

Pain that is in its early stages or poorly controlled, whether from nociceptive, neuropathic or mixed sources, ${ }^{4}$ and pain originating from metastases to bone $^{5}$ may respond to adjuvant electrical stimulation (Table 1). ${ }^{6-12}$

An often-cited early paper by Avellanosa and West ${ }^{6}$ indicates that good short-term pain relief from TENS is possible in patients with a wide range of malignant and post-surgical conditions. The paper is instructive because it describes the gradual induction of patients to the stimulation, i.e., beginning with electrodes initially positioned on non-pathological sites and subsequently moved to the related dermatome and finally to the skin over the most painful area. The authors reported some relatively minor negative outcomes from the TENS applications, i.e., local skin reactions under electrodes, short-term exacerbation of symptoms, and one instance of cardiac arrhythmia. All untoward effects were resolved by removal and repositioning of electrodes, and there were no reports of unwanted effects on tumour growth or spread.

After a promising start, controlled research studies have not been forthcoming. No strong evidence yet exists for the efficacy of TENS for the symptomatic relief of pain (acute or chronic) in cancer patients, nor do we find any guidelines for specific parameters of dose. ${ }^{13}$ One study reported a $60 \%$ improvement in facial pains with TENS but only in patients with low or moderate levels of pain. ${ }^{14}$ Generally the evidence suggests that stronger amplitudes are more likely to be effective than weaker ones, and that no particular 
Table 1 The use of TENS in managing cancer-related pain

\begin{tabular}{|c|c|c|c|c|}
\hline Reference & $\begin{array}{l}\text { Publication type } \\
\text { or study design }\end{array}$ & Sample/number & Parameters & Results \\
\hline $\begin{array}{l}\text { Avellanosa } \\
\text { and West } \\
(1982)^{6}\end{array}$ & Comparative study & 60 & $\begin{array}{l}\text { 85-180 Hz; } 80 \text { microseconds; } \\
1-180 \mathrm{~mA} \text { as tolerated; } \\
\text { Application } 10-14 \text { days }\end{array}$ & $\begin{array}{l}\text { Approx. } 30 \% \text { participants } \\
\text { had short term pain relief }\end{array}$ \\
\hline $\begin{array}{l}\text { Bauer } \\
(1983)^{7}\end{array}$ & Case studies & $\begin{array}{l}3 \text { patients with head } \\
\text { and neck pain }\end{array}$ & $\begin{array}{l}\text { Low amperage, low } \\
\text { frequency alternating currents }\end{array}$ & 'Extremely good results' \\
\hline $\begin{array}{l}\text { Jacox et al. } \\
(1994)^{8}\end{array}$ & $\begin{array}{l}\text { Clinical practice } \\
\text { guideline }\end{array}$ & 4 trials & Parameters not stated & $\begin{array}{l}\text { No significant difference } \\
\text { between TENS and } \\
\text { sham TENS }\end{array}$ \\
\hline $\begin{array}{l}\text { Ahmed et al. } \\
(1998)^{9}\end{array}$ & Case studies & 3 & $\begin{array}{l}\text { 4-100 Hz; } 30 \text { minutes; } \\
3 \text { treatments; } \\
\text { Percutaneous: needle } \\
\text { electrodes bilaterally at } \\
3 \text { spinal levels ( } 6 \text { channels) }\end{array}$ & $\begin{array}{l}\text { Short to medium term } \\
\text { analgesia in } 2 \text { cases }\end{array}$ \\
\hline $\begin{array}{l}\text { Robb et al. } \\
(2007)^{10}\end{array}$ & $\mathrm{RCT}$ & $\begin{array}{l}41 \text { women with pain } \\
\text { post treatment for } \\
\text { breast cancer }\end{array}$ & $\begin{array}{l}\text { Transcutaneous spinal } \\
\text { electroanalgesia (TSE); } \\
\text { Placebo (sham TSE) }\end{array}$ & $\begin{array}{l}\text { Outcomes not significantly } \\
\text { different to placebo }\end{array}$ \\
\hline $\begin{array}{l}\text { Searle et al. } \\
(2008)^{11}\end{array}$ & Pilot trial & 6 patients & $\begin{array}{l}\text { Single channel; } 80 \mathrm{~Hz} \text {; } \\
200 \text { microseconds; for } \\
30 \text { and } 60 \text { minutes on a } \\
\text { strong/comfortable intensity. }\end{array}$ & Pain outcomes improved \\
\hline $\begin{array}{l}\text { Robb et al. } \\
(2008)^{12}\end{array}$ & $\begin{array}{l}\text { Cochrane Database } \\
\text { review; meta-analysis } \\
\text { not possible }\end{array}$ & $\begin{array}{l}2 \text { RCT ( } 64 \text { patients with } \\
\text { chronic pain secondary } \\
\text { to breast cancer) }\end{array}$ & $\begin{array}{l}\text { TENS (Robb 2007) } \\
\text { AL-TENS }\end{array}$ & $\begin{array}{l}\text { No significant differences } \\
\text { between TENS and } \\
\text { placebo or sham }\end{array}$ \\
\hline
\end{tabular}

frequency is more effective than any other within the low frequency range $(1-120 \mathrm{~Hz}) .{ }^{15}$ The presence of the placebo effect with TENS is widely acknowledged in the literature, as are the positive effects that can occur when a patient is empowered with active control of some of the parameters, e.g., stimulation intensity, duration and number of sessions, and electrode positioning. ${ }^{16}$ There may be additional benefits for the patients' quality of life from complementary treatments, such as TENS, within the special environment of palliative care. ${ }^{16}$

Nowhere in the current body of literature is there a discussion of the risk of dissemination of cancerous cells by exogenous electrical currents. Possible reasons for the hiatus could be: in published papers the selection criteria excluded patients where the electrical currents' potential for dissemination was high; the anticipated short-term benefits of pain relief and improved quality of life were assumed to outweigh the longer term risk of spread of the disease; and with no tools for measuring dissemination effects the possibility for harm from this source remains theoretical.

Given the extent of its use, it is important to identify safety and efficacy factors related to electrical stimulation in the management of cancer pain. In the absence of definitive information on optimal treatment parameters, and without specific knowledge of the effects of electrical stimulation on malignant cells, it appears that judicious use of this modality needs the consideration of a number of factors. These factors include a thorough understanding of the malignancy (including tumour classification/stage); an understanding of the extent of the electric 'field' between and around electrodes; and the potential to stimulate malignant cells in vivo. Without a clear understanding of these factors, it continues to be reasonable to limit the use of TENS to the palliative stage only, as a means of symptom control.

The principle aim of treatment during the palliative stage of cancer care is to maintain or improve quality of life, 'through the prevention and relief of suffering by means of early identification and impeccable assessment and treatment of pain and other problems, physical, psychosocial and spiritual'. ${ }^{17}$ Where conventional methods of pain relief are inadequate, or where alternative methods are being trialled, it would be appropriate to trial TENS to reduce pain symptoms, or to manage pain (in conjunction with pharmacological agents). In this setting phase 1 or phase 2 research should elucidate the effectiveness of different stimulation parameters, and the influence of the site of electrode position. From the literature reviewed, on balance, compared with other medical interventions, and given that the usual safety precautions are applied, our opinion is that low amplitude TENS is safe for the palliative management of cancer pain.

Application of TENS in the curative stage (particularly if the success of cancer treatment has not yet been established) potentially places a patient at risk. In this setting research related to safety and efficacy trials should aim to establish a clear progression from preclinical through to phase 4 studies, with the first stage being an understanding of the effects of electrical current on a variety of malignant cells.

\section{Management of Side Effects of Cancer and Cancer Treatment}

Although there are a significant number of potential side effects from cancer and its treatment, the authors have limited the following discussion to those that are most commonly seen clinically. 


\begin{tabular}{|c|c|c|c|c|}
\hline Reference & $\begin{array}{l}\text { Publication type } \\
\text { or study design }\end{array}$ & Sample/number & Parameters & Results \\
\hline $\begin{array}{l}\text { Dundee et al. } \\
(1991)^{23}\end{array}$ & $\begin{array}{l}\text { Comparative } \\
\text { and crossover }\end{array}$ & $\begin{array}{l}100 \text { patients with } \\
\text { inadequately controlled } \\
\text { chemotherapy induced } \\
\text { nausea }\end{array}$ & $\begin{array}{l}15 \mathrm{~Hz}, 5 \text { minutes every } 2 \\
\text { hours (self-administered) } \\
\text { including over acupuncture } \\
\text { point P6 (Neiguan) }\end{array}$ & $\begin{array}{l}75 \% \text { effective } \\
\text { reduction of symptoms }\end{array}$ \\
\hline $\begin{array}{l}\text { Gadsby and } \\
\text { Franks }(1997)^{24}\end{array}$ & $\begin{array}{l}\text { Double blinded } \\
\text { randomized } \\
\text { controlled trial }\end{array}$ & $\begin{array}{l}15 \text { patients with nausea } \\
\text { and vomiting in } \\
\text { palliative care }\end{array}$ & $\begin{array}{l}3 \mathrm{~Hz}, 200 \text { milliseconds; } \\
30 \text { minutes applications, } \\
5 \text { days; } 4 \mathrm{~cm}^{2} \text { surface } \\
\text { electrode connecting P6 to Li4 }\end{array}$ & No significant effect \\
\hline $\begin{array}{l}\text { Ezzo et al. } \\
(2005)^{20}\end{array}$ & Review & $\begin{array}{l}11 \text { trials } \\
n=1247\end{array}$ & Electro-acupuncture & $\begin{array}{l}\text { Reduced severity of } \\
\text { chemotherapy induced } \\
\text { nausea and vomiting } \\
(P=0.04)\end{array}$ \\
\hline
\end{tabular}

\section{Nausea and vomiting}

Stimulation of the acupuncture point known as Neiguam or Pericardium 6 (P6) can reduce sensations of nausea and emesis. Electrical stimulation of P6 has been trialled in patients with symptoms either directly related to the disease or secondary to chemotherapy treatments, ${ }^{18-22}$ however the studies lacked rigour and the strength of the evidence is poor (Table 2). ${ }^{20,23,24}$

Most papers report that needle acupuncture was more effective than acupuncture-like TENS or manual pressures on the point..$^{23,24}$ The style of stimulation depends upon the availability of a trained professional required for dry needling versus the convenience and relative safety of self-applied methods, e.g., electronic wristbands. Authors agree that the clinical efficacy of exogenous stimulation must be weighed against the cost and availability of newer antiemetic medications and that responses to the TENS type treatments may have been affected by patient perceptions of issues regarding drug interactions, tolerance, and quantity of prescribed medications. Phase 1 research studies would appear to be appropriate for this area of practice.

\section{Muscle weakness and dysfunction}

With the increasing interest in applications of neuromuscular electrical stimulation (NMES) for rehabilitation after stroke, ${ }^{25}$ it is not surprising to find trials reporting good results for retardation or remediation of gait impairments, breathlessness and for urinary incontinence, in studies investigating the potential benefits of NMES for neuromotor indices of quality of life of cancer patients (Table 3) ${ }^{26-29}$ Indices of protein catabolism, quadriceps muscle strength and endurance, and functional gait respond to NMES in a small number of cases and controlled trials. ${ }^{26-28}$ However, post-prostatectomy patients with urinary incontinence appear not to gain real benefits from NMES, with or without biofeedback. ${ }^{30-33}$

Other researchers have shown improvement in dysphagia when NMES was applied to the throats of patients following radiation therapy for squamous cell carcinoma of the head and neck. ${ }^{29}$ The improvements may have been related to reductions in xerostomia (dry mouth) associated with radiotherapy treatment. In a recent Cochrane review ${ }^{34}$ of three RCT (comprising 50 chronic obstructive pulmonary

Table 3 The use of TENS in managing cancer-related muscle weakness and dysfunction

\begin{tabular}{|c|c|c|c|c|}
\hline Reference & $\begin{array}{l}\text { Publication type } \\
\text { or study design }\end{array}$ & Sample/number & Parameters & Results \\
\hline $\begin{array}{l}\text { McDuffie } \\
\text { and Morgan } \\
(2005)^{29}\end{array}$ & $\begin{array}{l}\text { Retrospective } \\
\text { review }\end{array}$ & 12 questionnaires & $\begin{array}{l}\text { 4-30 mA; 80-100 microseconds; } \\
3 \text { sessions per week for } \\
\text { 4-8 weeks. Four electrodes } \\
\text { placed along anterior neck } \\
\text { over pharyngeal muscles }\end{array}$ & $\begin{array}{l}\text { Improved xerostomia } \\
\text { and dysphagia in all } \\
\text { subjects }\end{array}$ \\
\hline $\begin{array}{l}\text { Crevenna } \\
\text { et al. } \\
(2006)^{28}\end{array}$ & Case study & $\begin{array}{l}\text { 47-year-old female } \\
\text { with advanced } \\
\text { lung cancer and } \\
\text { metastatic disease }\end{array}$ & $\begin{array}{l}\text { Combined with passive exercises } \\
5 \text { times per week for } 4 \text { weeks }\end{array}$ & $\begin{array}{l}\text { Improved 6-minute walk } \\
\text { distance, timed 'up-and-go', } \\
\text { SF-36 quality of life scale }\end{array}$ \\
\hline $\begin{array}{l}\text { Strasser } \\
\text { et al. } \\
(2009)^{26}\end{array}$ & $\begin{array}{l}\text { Assessor blinded } \\
\text { controlled trial }\end{array}$ & $\begin{array}{l}26 \text { people after } \\
\text { major abdominal } \\
\text { surgery for cancer }\end{array}$ & $\begin{array}{l}50 \mathrm{~Hz} \text {; } 250 \text { microseconds; } 8 \\
\text { seconds on } 4 \text { seconds off; for } 30 \\
\text { minutes, for } 4 \text { consecutive days } \\
\text { starting day } 1 \text { post-op at maximum } \\
\text { tolerable intensity for quadriceps } \\
\text { muscle contraction; control was } \\
\text { contralateral thigh (same } \\
\text { parameters; intensity gentle tingling) }\end{array}$ & $\begin{array}{l}\text { Positive effects on protein } \\
\text { catabolism }(P=0.008) \text { and } \\
\text { reduction of muscle } \\
\text { degradation }(P=0.029)\end{array}$ \\
\hline $\begin{array}{l}\text { Maddocks } \\
\text { et al. } \\
(2007)^{27}\end{array}$ & $\begin{array}{l}\text { Randomized } \\
\text { controlled } \\
\text { pilot study }\end{array}$ & $\begin{array}{l}16 \text { patients with } \\
\text { cachexia due to } \\
\text { lung cancer }\end{array}$ & $\begin{array}{l}50 \mathrm{~Hz} \text {; 0-120 mA; duty cycle } \\
11-25 \% \text {; delivered over } 1 \text { hour to } \\
\text { the quadriceps for } 4 \text { weeks }\end{array}$ & $\begin{array}{l}\text { Non-significant increases } \\
\text { in quads muscle strength } \\
\text { and exercise endurance }\end{array}$ \\
\hline
\end{tabular}


disease patients), NMES (ranging from 15 to 30 minutes to quadriceps muscles; 3-5 times per week for 4-6 weeks) resulted in improvements in ratings of perceived exertion and shuttle walk test, and decreased dyspnoea in patients in advanced stages of malignant and non-malignant disease. Although a meta-analysis was not possible, the RCT were considered of high quality.

For the authors' views on the appropriateness and need for research in the field of NMES for motor control factors in cancer care, the reader is referred to the previous section on electrical stimulation for cancer pain.

\section{Breast cancer-related lymphoedema (BCRL)}

Lymphoedema of the upper limb is a side effect of the surgical management of breast cancer, or of radiation damage to the lymphatic system. Less commonly, lower limb lymphoedema occurs following surgery for gynaecological cancers, or other pelvic cancers, in females and males. This discussion is limited to BCRL for which there is no definitive cure. Physical treatment includes patient education and self-management strategies, compression bandages and sleeves, manual lymphatic drainage, massage and range of motion exercises (alone or in combination). Recently laser phototherapy and ultrasound have been trialled for BCRL. Lymphoedema research is hampered by the absence of a gold standard outcome measure hence definitive conclusions regarding interventions are difficult to make.

\section{Therapeutic ultrasound}

Little is known about the effectiveness of ultrasound for BCRL. Only one study on the subject was located. The researchers compared US given to 50 BCRL patients, with standardized compression pump treatments provided to 100 other women with the condition. ${ }^{35}$ The US application was different to usual musculoskeletal style of treatment in which the transducer emits low levels of temporal and spatially averaged energy. Instead, ten stationary transducers were positioned over acupuncture points that had been used previously in experiments of low level laser for lymphoedema. The transducers emitted a peak power of $2 \mathrm{~W} / \mathrm{cm}^{2}$ at $3 \mathrm{MHz}$. The treatment program consisted of 2 cycles of 10 sessions, each session lasting for 30 minutes. The US mode was pulsed but the duty cycle was not specified. The study found that, at 4-month follow-up, the US group had reductions in circumferential limb size that were not statistically different from the compression pump group and did not persist at 12 months. However the patients who received US reported some advantages of the therapy e.g., relatively softer $\operatorname{limb}$ tension, lower levels of musculoskeletal pain and discomfort, and a satisfaction that they had avoided the need to wear a compression sleeve.

\section{Electrical stimulation}

Very few papers describe the external use of electrical stimulation in humans with lymphoedema. In 1991, Bertelli et al. ${ }^{36}$ described an RCT comparing elastic sleeves worn for 6 months with sleeves plus electrical stimulation. There were no significant differences between groups for reductions of limb girth. More recently a dedicated electrical stimulation device (Bodyflow $^{\mathrm{TM}}$; Bodyflow International, Collingwood, Victoria, Australia) has been developed with the intention to stimulate the smooth muscle pump within the active anatomical units of the lymphatic system (the lymphangion). Research in animals supports neuromuscular stimulation of smooth muscle fibres with low amplitude, low frequency $(1.5 \mathrm{~Hz})$ currents, however published clinical trials with this device are few and low powered. Piller et al. ${ }^{37}$ describe the use of low frequency electrical stimulation in conjunction with compression garments for lymphoedema of the lower limbs. The study was low powered, mainly because patients had difficulty complying with the need to wear compression garments and electrodes concurrently. With regard to safety, treatments to the lower limb may be less problematic than applications to proximal regions of the upper limb when consideration is given to the potential for unsafe electrical stimulation of the autonomic neural plexes. Preclinical through to phase 1 research may explicate some of the issues related to the application of electrical stimulation for lymphoedema.

\section{Low level laser therapy}

The earliest example of using LLLT to influence the lymphatic system is the work of Lievens ${ }^{38}$ who examined the effect of helium-neon $(\mathrm{HeNe})$ and gallium arsenide (GaAs) laser $(904 \mathrm{~nm})$ on lymph vessels and healing after surgically-inducing wounds in mice. Thelander and Piller ${ }^{39}$ raised awareness of laser phototherapy as a clinical treatment strategy for BCRL in a report of 11 subjects with the condition (participants acted as their own controls). Using a scanning laser with $\mathrm{HeNe}$ and infrared wavelengths $\left(2-4 \mathrm{~J} / \mathrm{cm}^{2}\right)$ they recorded $19.3 \%$ average reduction in lymphoedema at the end of treatment; and a $26 \%$ average reduction in BCRL at 6-month follow-up.

Three studies ${ }^{40-42}$ evaluated the efficacy of LLLT alone or in combination with pneumatic compression and/or exercise. In a double blind, placebo-controlled, randomized, single crossover trial, ${ }^{40}$ a significant number of participants did not benefit from LLLT, although improvement in $31 \%$ of participants is benefit that may not have been gained by other means. In general, studies in this field are characterized by low participant numbers and disparate intervention parameters yet each study reports benefits from LLLT for outcomes of tissue softening, arm volume, limb circumference and pain when 
compared to control and/or placebo group participants. Follow-up measures in these studies suggest maintenance of the improvement in outcomes. Despite increasing interest, evidence remains limited, and disparate methodological designs make it difficult to decide which LLLT parameters are most effective in the management of BCRL.

Despite encouraging reports of benefit from LLLT in cases of BCRL, little regard has been paid to its safety in the (possible) presence of malignant cells. The potential for stimulating growth or spread of malignant cells using LLLT is poorly understood. Mikhailov et $a l^{43}$ examined recurrence rates in 41 patients with BCRL who developed post-operative complications and were subsequently treated with LLLT. Specific details of the treatments and patient groups are unclear. However, $87 \%$ and $77.7 \%$ of patients with Stage II and Stage III breast cancer respectively, treated with LLLT had no disease recurrence over a 10 -year follow-up period. Although the cohort numbers are small, the figures compare with known data ${ }^{44}$ suggesting that the addition of laser phototherapy has no effect on survival or disease recurrence.

In an attempt to address the safety question, one of the authors (LL) has investigated whether laser irradiation has the capacity to promote cancer cell growth and the dose-response characteristics of laser in malignant cells in culture. ${ }^{45,46}$ Utilizing three common laser wavelengths (780, 830, and $904 \mathrm{~nm}$ ) and a range of doses, ${ }^{46}$ the results in human mammary epithelial and human breast cancer cells (adenocarcinoma and ductal carcinoma) demonstrate that one line of mammary epithelial cells proliferated significantly after exposure to a range of doses at 780 and $904 \mathrm{~nm}$. A second line of mammary epithelial cells and a ductal carcinoma cell line showed negligible effects with one exposure from all wavelengths. Human breast adenocarcinoma cells irradiated with $780 \mathrm{~nm}$ laser demonstrated an increasing dose response relationship after one exposure, yet a decreasing dose response relationship after three exposures. When irradiated with $904 \mathrm{~nm}$ laser, the same cells demonstrated a decreasing dose response relationship after two and three exposures. In these studies, laser did not malignantly transform cells confirming that low intensity laser is not a carcinogen.

The next step should be to translate the findings into preclinical animal models before a more systematic investigation of wavelengths and doses in clinical settings. Research of safety and efficacy issues must progress from preclinical through to phase 4 studies before the use of laser for this indication can be assured.

\section{Oral mucositis}

Oral mucositis is an inflammatory reaction to radiotherapy or chemotherapy applied in a range of cancers across the continuum of cancer care (through curative to palliative stages). The reported incidence of oral mucositis ranges from 36 to $100 \%{ }^{47}$ Therefore a measure to prevent or manage cancer treatmentinduced oral mucositis would have significant benefits for patient quality of life, and on resultant costs related to bed days and length of hospital stay.

Ciais et al. ${ }^{47}$ were the first to publish a case series describing the use and potential benefit of LLLT for oral mucositis caused by cancer treatment. Subsequently, a range of authors has investigated the efficacy of LLLT for oral mucositis in welldesigned prospective, blinded and controlled trials (Table 4). ${ }^{47-60}$

The majority of reports demonstrate significant improvement in a range of indicators including pain, severity, erythema, oedema, ulceration and atrophy. The results are not unexpected based on existing knowledge of the healing response of soft tissues to laser phototherapy. ${ }^{61}$ The outcomes of the research listed in Table 4 clearly demonstrate that laser phototherapy using wavelengths in the visible range of the electromagnetic spectrum (e.g., HeNe, $632.8 \mathrm{~nm}$ ) and in a fluence range less than $2.5 \mathrm{~J} / \mathrm{cm}^{2}$, has significant potential in the prevention or management of cancerrelated oral mucositis (and perhaps mucositis in other parts of the body).

Despite the evidence supporting its potential use, there remains the unknown factor of what effect the laser irradiation of mucous membranes may have on cancer cells in the immediate vicinity. It is worth noting that after an initial surge in research investigating the treatment, some are now questioning the safety of applying LLLT in close association with cancer. ${ }^{62}$ Research related to safety and efficacy trials should be undertaken before the use of laser for this indication becomes more widespread, e.g., phase 1 and phase 2 testing for dose-response effects in palliative patient samples.

\section{Potential of EPAs for Cancer Treatment}

It is interesting to note that electromagnetic energies (such as magnetic fields) are being investigated to treat cancer cell lines albeit in experimental models, e.g. Subo et $a l .{ }^{63}$ Should physiotherapists and research colleagues be taking another perspective of these developments?

\section{Therapeutic ultrasound}

Therapeutic ultrasound applications are absolutely contraindicated directly over cancerous lesions or where a tumour or malignancy is suspected. ${ }^{64}$ Ultrasound has been shown to stimulate tumour growth and dissemination, ${ }^{65}$ whether or not the output mode of the device is continuous or pulsed ${ }^{66}$ and is therefore considered contraindicated.

Recently however, the attention of researchers has been drawn to the potential of low intensity ultrasound, and its bio-effects, as an agent of active treatment for cancer. Cavitations caused by low 
Table 4 The application of LLLT in managing cancer-related oral mucositis

\begin{tabular}{|c|c|c|c|c|}
\hline Reference & Study design & Participants/number & Laser parameters* & Results \\
\hline $\begin{array}{l}\text { Ciais et al. } \\
(1992)^{47}\end{array}$ & $\begin{array}{l}\text { Descriptive case } \\
\text { series (retrospective, } \\
\text { non-randomized } \\
\text { study) }\end{array}$ & $\begin{array}{l}\text { Variety of patients } \\
\text { receiving combination } \\
\text { chemotherapy: } n=67\end{array}$ & $\begin{array}{l}\text { HeNe } 632.8 \mathrm{~nm}, \mathrm{cw} \\
25 \mathrm{~mW} ; 0.75 \mathrm{~J} / \mathrm{cm}^{2} \\
\text { total } 54 \mathrm{~J}\end{array}$ & $\begin{array}{l}\text { Reduction in: time to healing } \\
\text { and incidence of oral } \\
\text { complications }\end{array}$ \\
\hline $\begin{array}{l}\text { Pourreau- } \\
\text { Schneider } \\
\text { et al. } \\
(1992)^{48}\end{array}$ & $\begin{array}{l}\text { Retrospective } \\
\text { case review }\end{array}$ & $\begin{array}{l}\text { Patients undergoing } \\
\text { combination } \\
\text { chemotherapy for a } \\
\text { variety of cancers; } \\
\text { laser: } n=16 \text {; no laser: } \\
n=20 ; \text { prophylactic } \\
\text { laser: } n=23\end{array}$ & $632 \mathrm{~nm}$ laser, $25 \mathrm{~mW}$ & $\begin{array}{l}\text { Time to resolution of mucositis } \\
\text { was faster in both laser treated } \\
\text { groups. Severity and incidence } \\
\text { of mucositis lower in } \\
\text { prophylactic laser group }\end{array}$ \\
\hline $\begin{array}{l}\text { Franquin } \\
\text { et al. } \\
(1994)^{49}\end{array}$ & $\begin{array}{l}\text { Randomized } \\
\text { phase II study }\end{array}$ & $\begin{array}{l}\text { Autologous BMT patients: } \\
n=24 \text {; two groups (daily } \\
\text { active laser; and sham } \\
\text { control) }\end{array}$ & $\begin{array}{l}632 \mathrm{~nm}, \mathrm{cw} \\
60 \mathrm{~mW}, 1.5 \mathrm{~J} / \mathrm{cm}^{2}\end{array}$ & $\begin{array}{l}\text { Significant decrease }(P<0.01) \\
\text { of incidence, severity and the } \\
\text { duration of mucositis }\end{array}$ \\
\hline $\begin{array}{l}\text { Schubert } \\
\text { et al. } \\
(1994)^{50}\end{array}$ & $\begin{array}{l}\text { Non-blinded open } \\
\text { phase I/II pilot study } \\
\text { with comparison to } \\
\text { an historical disease } \\
\text { and treatment } \\
\text { matched control } \\
\text { group }\end{array}$ & $\begin{array}{l}\text { Patients undergoing BMT } \\
\text { chemotherapy: } n=13\end{array}$ & $\begin{array}{l}\text { GaAs }(n=6) \text { or } \\
\text { HeNe }(n=7) \text {, once a } \\
\text { day for } 3 \text { weeks }\end{array}$ & $\begin{array}{l}\text { Mean oral pain scores and oral } \\
\text { mucositis index improved in } \\
\text { patients who received laser } \\
\text { compared to controls }\end{array}$ \\
\hline $\begin{array}{l}\text { Barasch } \\
\text { et al. } \\
(1995)^{51}\end{array}$ & $\begin{array}{l}\text { Prospective, } \\
\text { double-blind, } \\
\text { controlled study } \\
\text { (split-mouth design) }\end{array}$ & $\begin{array}{l}\text { BMT patients undergoing } \\
\text { chemotherapy and XRT: } \\
n=20 \text { completions }\end{array}$ & $\begin{array}{l}\text { HeNe } 632.8 \mathrm{~nm}, \mathrm{cw} \\
25 \mathrm{~mW}, 1 \mathrm{~J} / \mathrm{cm}^{2} \\
0.8 \mathrm{~cm}^{2} \text { aperture, } \\
40 \text {-second exposures, } \\
\text { daily for } 5 \text { days }\end{array}$ & $\begin{array}{l}\text { Oral mucositis index }(P<0.005) \\
\text { and VAS pain }(P=0.027) \\
\text { significantly better on treated } \\
\text { side }\end{array}$ \\
\hline $\begin{array}{l}\text { Cowen } \\
\text { et al. } \\
(1997)^{52}\end{array}$ & $\begin{array}{l}\text { Prospective, } \\
\text { double-blind } \\
\text { randomized study }\end{array}$ & $\begin{array}{l}\text { Patients undergoing BMT: } \\
n=30 \text { completions }\end{array}$ & $\begin{array}{l}\text { HeNe } 632.8 \mathrm{~nm}, \mathrm{cw} \\
60 \mathrm{~mW}, 1.5 \mathrm{~J} / \mathrm{cm}^{2} \\
\text { total=54 } \mathrm{J} / \text { session, } \\
0.8 \mathrm{~cm}^{2} \text { aperture, } \\
40 \text {-second exposures, } \\
\text { daily for } 5 \text { days }\end{array}$ & $\begin{array}{l}\text { Maximum intensity }(P=0.04) \\
\text { and severity }(P=0.01) \text { of oral } \\
\text { mucositis, use of morphine } \\
(P=0.05) \text {, saliva production } \\
(P=0.005) \text { and ability to } \\
\text { swallow ( } P=0.01) \text { significantly } \\
\text { reduced in laser group }\end{array}$ \\
\hline $\begin{array}{l}\text { Bensadoun } \\
\text { et al. } \\
(1999)^{53}\end{array}$ & $\begin{array}{l}\text { Multicentre phase III, } \\
\text { double-blind, } \\
\text { randomized } \\
\text { study; laser versus } \\
\text { sham laser }\end{array}$ & $\begin{array}{l}\text { Patients with carcinoma of } \\
\text { the oropharynx, } \\
\text { hypopharynx and oral } \\
\text { cavity treated by } \\
\text { external radiotherapy: } \\
n=28 \text { completions }\end{array}$ & $\begin{array}{l}\text { HeNe } 632.8 \mathrm{~nm}, \mathrm{cw}, \\
60 \text { and } 25 \mathrm{~mW} \text {, } \\
2 \mathrm{~J} / \mathrm{cm}^{2}, 1.2 \mathrm{~mm} \\
\text { spot size, } 33 \\
\text { seconds per point to } \\
9 \text { points, daily for } \\
5 \text { days each week } \\
\text { for } 7 \text { weeks }\end{array}$ & $\begin{array}{l}\text { Mean intensity }(P=0.01) \text { and } \\
\text { grading of mucositis }(P=0.001) \\
\text { and pain }(P=0.025) \text {, pain } \\
\text { intensity }(P=0.001) \text { and ability } \\
\text { to swallow }(P=0.01) \text { significantly } \\
\text { better in laser group }\end{array}$ \\
\hline $\begin{array}{l}\text { Migliorati } \\
\text { et al. } \\
(2001)^{54}\end{array}$ & Pilot trial in series & $\begin{array}{l}\text { Patients requiring BMT for } \\
\text { variety of haematological } \\
\text { and solid tumours: } n=11\end{array}$ & $\begin{array}{l}\text { GaAlAs } 780 \mathrm{~nm}, \\
60 \mathrm{~mW}, 2 \mathrm{~J} / \mathrm{cm}^{2} \\
\text { daily for } 10 \text { days }\end{array}$ & Equivocal results \\
\hline $\begin{array}{l}\text { Wong and } \\
\text { Wilder- } \\
\text { Smith } \\
(2002)^{55}\end{array}$ & Pilot study & $\begin{array}{l}\text { Patients undergoing } \\
\text { chemotherapy for variety } \\
\text { of cancers and with prior } \\
\text { history of oral mucositis: } \\
n=15\end{array}$ & $\begin{array}{l}830 \mathrm{~nm}, \mathrm{cW}, \\
45-50 \mathrm{~mW}, \\
0.7-0.8 \mathrm{~J} / \mathrm{cm}^{2}, \\
\text { total } 50-60 \mathrm{~J}, \\
24 \mathrm{~h} \text { prior to } \\
\text { commencement } \\
\text { of chemotherapy } \\
\text { and weekly thereafter }\end{array}$ & $\begin{array}{l}11 \text { of } 15 \text { patients had no } \\
\text { mucositis and of remainder, } \\
\text { one had high grade (severe) } \\
\text { and others had low grade } \\
\text { mucositis. No change in } \\
\text { measured intraoral perfusion } \\
(P<0.05)\end{array}$ \\
\hline $\begin{array}{l}\text { Nes and } \\
\text { Posso } \\
(2005)^{56}\end{array}$ & $\begin{array}{l}\text { Case series } \\
\text { (patients as } \\
\text { own controls) }\end{array}$ & $\begin{array}{l}\text { Patients with cancer } \\
\text { undergoing chemotherapy } \\
\text { resulting in oral mucositis: } \\
n=13\end{array}$ & $\begin{array}{l}\text { AsGaAl } 830 \mathrm{~nm} \text {, } \\
250 \mathrm{~mW}, 35 \mathrm{~J} / \mathrm{cm}^{2} \\
\text { spot diameter } \\
0.60 \mathrm{~mm} \text {, daily } \\
\text { for } 5 \text { days }\end{array}$ & $\begin{array}{l}\text { Significantly lower pain scores } \\
(P=0.007) \text { after laser treatment } \\
\text { compared to pre-laser scores }\end{array}$ \\
\hline $\begin{array}{l}\text { Maiya et al. } \\
(2006)^{57}\end{array}$ & $\begin{array}{l}\text { Prospective, } \\
\text { assessor-blinded } \\
\text { randomized } \\
\text { controlled } \\
\text { clinical trial }\end{array}$ & $\begin{array}{l}\text { Cancer of oral cavity } \\
\text { undergoing XRT: } n=50 \\
\text { completions }\end{array}$ & $\begin{array}{l}\text { HeNe } 632.8 \mathrm{~nm}, \\
10 \mathrm{~mW}, 1.8 \mathrm{~J} / \mathrm{cm}^{2} \\
\text { delivered over } \\
3 \text { minutes. }\end{array}$ & $\begin{array}{l}\text { Mean pain ranking }(P<0.001) \\
\text { and pain scores }(P<0.001) \text {, } \\
\text { and mucositis grade (severity) } \\
(P<0.001) \text { significantly reduced } \\
\text { in laser group }\end{array}$ \\
\hline $\begin{array}{l}\text { Cruz et al. } \\
(2007)^{58}\end{array}$ & $\begin{array}{l}\text { Prospective, } \\
\text { randomized } \\
\text { clinical trial }\end{array}$ & $\begin{array}{l}\text { Paediatric patients with } \\
\text { solid or haematological } \\
\text { malignancies: } n=60 ; \\
\text { completions: control } n=31 \\
\text { versus laser } n=29\end{array}$ & $\begin{array}{l}780 \mathrm{~nm}, \mathrm{cw}, 60 \mathrm{~mW}, \\
4 \mathrm{~J} / \mathrm{cm}^{2} \\
5 \text { consecutive days }\end{array}$ & $\begin{array}{l}\text { Incidence }(P=0.649) \text { and } \\
\text { severity }(P=0.234) \text { of oral } \\
\text { mucositis was similar in } \\
\text { both groups }\end{array}$ \\
\hline $\begin{array}{l}\text { Jaguar } \\
\text { et al. } \\
(2007)^{59}\end{array}$ & $\begin{array}{l}\text { Comparative } \\
\text { group study }\end{array}$ & $\begin{array}{l}\text { Patients undergoing BMT; } \\
\text { total } n=49 \text { (laser } \\
n=24 \text { versus } \\
\text { historical control } n=25\end{array}$ & $\begin{array}{l}660 \mathrm{~nm}, \mathrm{cw}, 10 \mathrm{~mW} \\
2.5 \mathrm{~J} / \mathrm{cm}^{2} \\
10 \text { seconds } \\
\text { per point. }\end{array}$ & $\begin{array}{l}\text { Significantly delayed onset of } \\
\text { mucositis }(P=0.01) \text {. Duration of } \\
\text { pain }(P=0.04) \text { and requirement } \\
\text { for morphine }(P=0.07) \text { was } \\
\text { significantly less in laser group. } \\
\text { Grading of mucositis was } \\
\text { unchanged between groups. }\end{array}$ \\
\hline
\end{tabular}




\begin{tabular}{lllll}
\hline Reference & Study design & Participants/number & Laser parameters* & Results \\
\hline Arora & Single centre, & Newly diagnosed & HeNe $632.8 \mathrm{~nm}$, & Pain significantly decreased in \\
et al. & prospective, & primary oral cancer: & $10 \mathrm{~Hz} \mathrm{scanning,}$ & laser group compared to control \\
$(2008)^{60}$ & controlled group & $n=24$ completions & $10 \mathrm{~mW}, 1.8 \mathrm{~J} / \mathrm{cm}^{2}$ & $(P=0.033) ;$ significantly lower \\
& comparison study & (11 laser and 13 & for 5 minutes & mucositis grading in laser group \\
& & controls) & daily over 8 days & across all weeks (e.g., week 1: \\
& & & $P=0.004 ;$ week 7: $P=0.045)$ \\
\hline
\end{tabular}

Notes: *Order of presentation of parameters where supplied: wavelength, continuous or pulsed wave, power, fluence, total energy, diode aperture size, number of exposures/treatment, treatment frequency and duration.

BMT, bone marrow transplant; XRT, radiation therapy; HeNe, helium-neon; cw, continuous wave; GaAs, gallium arsenide; GaAlAs, gallium-aluminium-arsenide; AsGaAl, arsenide-gallium-aluminium; VAS, Visual Analogue Scale.

intensity ultrasound may enhance the actions of chemotherapeutic drugs and the transfer of genetic material. ${ }^{67}$ Reviewers describe a range of changes to cell structure, from reversible permeation through degrees of damage to cell death, and effects on function, such as proliferation, migration and synthesis, that all depend directly on US dose (amplitude, frequency and time of application). ${ }^{68}$ Animal studies have demonstrated that, compared to their healthy neighbours, the cells of cancers and mildly hyperthermic or chemically sensitized tissues have a lower threshold for apoptosis and lysis when exposed to low amplitude ultrasound. ${ }^{69}$ Other authors, noting the augmentation of the destructive effects of ultrasound with even small increases in tissue temperature (e.g., from baseline to $40^{\circ} \mathrm{C}$ ) suggested that the effects of ultrasonic imaging in febrile patients be investigated. ${ }^{70}$ For the same reason therapeutic applications of ultrasound should be avoided in patients with fever until safe dosages have been established, perhaps in pre-clinical animal studies.

\section{Microwave thermotherapy}

In a phase 2 dose-escalation study of 25 patients, Vargas and colleagues ${ }^{71}$ utilized the thermal effects of focused microwave energy to induce pathologic necrosis in early stage breast cancer tumours. Treatment tolerance was excellent and all patients underwent tumour excision on average 17 days after thermotherapy. Two cases demonstrated complete tumour ablation and in the remainder, the extent of tumour necrosis ranged from 25 to $90 \%$ depending on the dose applied. Side effects were noted in particular at higher doses and included short-lived erythema, reports of mild to severe pain, oedema and three reports of skin thermal burns.

\section{Low level laser therapy}

The findings of Powell et al. ${ }^{46}$ noted earlier, raise the possibility that repeated laser treatment may have a protective effect or even an inhibitory effect on malignant cell proliferation. Santana-Blank ${ }^{72}$ had previously suggested that laser therapy be considered as a potential treatment for cancer. The preclinical laboratory evidence supports this possibility (e.g. ${ }^{45,46}$ ) and the potential deserves greater attention in animal studies.

\section{Conclusion}

There is sufficient evidence to suggest that certain EPAs have a role in the management of the sequelae of cancer and cancer treatment, and perhaps directly for particular cancers. There is a need for further study that, like pharmaceutical industry research, systematically investigates the effect of EPAs on malignant cells in culture (across a range of dosing parameters) and in animal models (using dosing parameters established as 'safe' in cell culture studies), and later in phase 1 and 2 clinical trials to establish safety and efficacy. Suitable models for such testing are imperative with the possibility that such models could then be used to test the effects of a range of EPAs in malignant conditions.

\section{References}

1 Robertson V, Chipchase L, Laakso L, Whelan K. Guidelines for the safe use of electrophysical agents. Melbourne: Australian Physiotherapy Association; 2001.

2 Chartered Society of Physiotherapists. Guidance for the clinical use of electrophysical agents. London: Chartered Society of Physiotherapists; 2006.

3 Grond S, Radbruch L, Meuser T, Sabatowski R, Loick G, Lehmann KA. Assessment and treatment of neuropathic cancer pain following WHO guidelines. Pain 1999;79:15-20.

4 Fiscus KA, Kaminski TW, Powers ME. Changes in lower-leg blood flow during warm-, cold- and contrast-water therapy. Arch Phys Med Rehabil 2005;86:1404-10.

5 Khor KE, Ditton JN. Femoral nerve blockade in the multidisciplinary management of intractable localized pain due to metastatic tumor: a case report. J Pain Symptom Manage 1996;11:57-6.

6 Avellanosa AM, West CR. Experience with transcutaneous electrical nerve stimulation for relief of intractable pain in cancer patients. J Med 1982;13:203-13.

7 Bauer W. Electrical treatment of severe head and neck cancer pain. Arch Otolaryngol 1983;109:382-83.

8 Jacox A, Carr DB, Payne R. Management of cancer pain. Clinical practice guideline no. 9. 1994 [cited 2010 Mar 18]. Available from http://www.hospicepatients.org/ clinicalpracticeguidelines1994.html.

9 Ahmed HE, Craig WF, White PF, Huber P. Percutaneous electrical nerve stimulation (PENS): a complementary therapy for the management of pain secondary to bony metastasis. Clin J Pain 1998;14:320-23.

10 Robb KA, Newham DJ, Williams JE. Transcutaneous electrical nerve stimulation vs. transcutaneous spinal electroanalgesia for chronic pain associated with breast cancer treatments. J Pain Symptom Manage 2007;33:410-19.

11 Searle R, Bennett M, Johnson MI, Callin S, Radford H. Letter to editor: transcutaneous electrical nerve stimulation (TENS) for cancer bone pain. Palliat Med 2008;22:878-79.

12 Robb K, Bennett MI, Johnson MI, Simpson KH, Oxberry SG. A Cochrane systematic review of transcutaneous electrical 
nerve stimulation for cancer pain. Cochrane Database Syst Rev 2008;(3):CD006276.

13 Robb K, Oxberry SG, Bennett MI, Johnson MI, Simpson KH, Searle RD. A Cochrane systematic review of transcutaneous electrical nerve stimulation for cancer pain. J Pain Symptom Manage 2009;37:746-53.

14 Chiarini L, Stacca R, Bertoldi C, Malagnino F, Pollastri G, Narni F. Management of facial pain resulting from cancer in oral and maxillofacial surgery. Minerva Stomatol 1997;46(1-2):27-38; In: Bercovitch M, Waller A, editors. Oxford textbook of palliative medicine. 3rd ed. Oxford: Oxford University Press; 2005.

15 Nnoaham KE, Kumbang J. Transcutaneous electrical nerve stimulation (TENS) for chronic pain. Cochrane Database Syst Rev 2008;(3):CD003222.

16 Hall E, Sykes NP. Analgesia for patients with advanced disease: I. Postgrad Med J 2004;80:148-54.

17 World Health Organisation (WHO), Definition of palliative care. [cited 2010 Feb 25]. Available from: http://www.who.int/ cancer/palliative/definition/en/.

18 Pearl ML, Fischer M, McCauley DL, Valea FA, Chalas E. Transcutaneous electrical nerve stimulation as an adjunct for controlling chemotherapy-induced nausea and vomiting in gynecologic oncology patients. Cancer Nurs 1999;22,307-11.

19 Ozgür Tan M, Sandikçi Z, Uygur MC, Arik AI, Erol D. Combination of transcutaneous electrical nerve stimulation and ondansetron in preventing cisplatin-induced emesis. Urol Int 2001;67:54-58

20 Ezzo J, Vickers A, Richardson MA, Allen C, Dibble SL, Issell $\mathrm{B}$, et al. Acupuncture-point stimulation for chemotherapyinduced nausea and vomiting. J Clin Oncol 2005;23:7188-98.

21 Roscoe JA, Matteson SE, Morrow GR, Hickok JT, Bushunow P, Griggs $\mathbf{J}$, et al. Acustimulation wrist bands are not effective for the control of chemotherapy-induced nausea in women with breast cancer. J Pain Symptom Manage 2005;29:376-84.

22 Rowbotham DJ. Recent advances in the non-pharmacological management of postoperative nausea and vomiting. $\mathrm{Br}$ Anaesth 2005;95:77-81.

23 Dundee JW, Yang J, McMillan C. Non-invasive stimulation of the P6 (Neiguan) antiemetic acupuncture point in cancer chemotherapy. J R Soc Med 1991;84:210-12.

24 Gadsby JG, Franks A. Acupuncture-like transcutaneous electrical nerve stimulation within palliative care: a pilot study. Complement Ther Med 1997;5:13-18.

25 Langmore SE, Grillone G, Elackattu A, Walsh M. Disorders of swallowing: palliative care. Otolaryngol Clin North Am 2009;42:87-105.

26 Strasser EM, Stättner S, Karner J, Klimpfinger M, Freynhofer M, Zaller V. Neuromuscular electrical stimulation reduces skeletal muscle protein degradation and stimulates insulin-like growth factors in an age- and current-dependent manner: a randomized, controlled clinical trial in major abdominal surgical patients. Ann Surg 2009;249:738-43.

27 Maddocks M, Mockett S, Wilcock A. Neuromuscular electrical stimulation (NMES): a reactive palliative therapy, a proactive supportive therapy or both? Support Care Cancer 2007;15:111

28 Crevenna R, Marosi C, Schmidinger M, Fialka-Moser V. Neuromuscular electrical stimulation for a patient with metastatic lung cancer - a case report. Support Cancer Care 2006;14:970-73.

29 McDuffie CM, Morgan M. Electrical stimulation of postirradiated head and neck SCCA. Otolaryngol Head Neck Surg 2005; 133:101-101

30 Wille S, Sobottka A, Heidenreich A, Hofmann R. Pelvic floor exercises, electrical stimulation and biofeedback after radical prostatectomy: results of a prospective randomized trial. J Urol 2003;170:490-93

31 Bezerra CA, Wroclawsky ER Randomized clinical trials do not show that PFMT + vaginal electrical stimulation is better than electrical stimulation. J Urol 2009;181:561-61.

32 Goode PS, Burgio KL, Johnson TM, Roth DL, Clay OJ, Burkhardt $\mathrm{JH}$, et al. Pelvic floor electrical stimulation, biofeedback, and behavioral therapy for persistent post prostatectomy incontinence. J Urol 2009;181:591-92.

33 Mariotti G, Sciarra A, Gentilucci A, Salciccia S, Alfarone A, Pierro GD, et al. Early recovery of urinary continence after radical prostatectomy using early pelvic floor electrical stimulation. J Urol 2009;181:1788-93.

34 Bausewein C, Booth S, Gysels M, Higginson I. Non-pharmacological interventions for breathlessness in advanced stages of malignant and non-malignant diseases. Cochrane Database Syst Rev 2008;(2):CD005623.

35 Balzarini A, Pirovani C, Diazzi G, Olivieri R, Ferla F, Galperti G, et al. Ultrasound therapy of chronic arm lymphedema after surgical treatment of breast cancer. Lymphology 1993;26:128-34.
36 Bertelli G, Venturini M, Forno G, Macchiavello F, Dini D. Conservative treatment of postmastectomy lymphedema: a controlled, randomized trial. Ann Oncol 1991;2:575-78.

37 Piller N, Moseley A. Results of a single blinded placebo controlled trial of the Bodyflow ${ }^{\mathrm{TM}}$ technique for the treatment of lymphoedema of the legs. Sydney: Australasian College of Phlebology; 2007.

38 Lievens PC. The effect of a combined HeNe and IR laser treatment on the regeneration of the lymphatic system during the process of wound healing. Laser Med Sci 1991;6:193-99.

39 Thelander A, Piller N. Helium neon and infra-red laser therapy reduces the severity of chronic post mastectomy lymphoedema. Laser Ther 1994;6:63.

40 Carati CJ, Anderson SN, Gannon BJ, Piller NB. Treatment of postmastectomy lymphedema with low-level laser therapy. A double blind, placebo-controlled trial. Cancer 2003;98:1114-22.

41 Kaviani A, Fateh M, Yousefi Nooraie R, Alinagi-zadeh MR, Ataie-Fashtami L. Low-level laser therapy in management of postmastectomy lymphedema. Lasers Med Sci 2006;21:90-94.

42 Kozanoglu E, Basaran S, Paydas S, Sarpel T. Efficacy of pneumatic compression and low-level laser therapy in the treatment of postmastectomy lymphoedema: a randomized controlled trial. Clin Rehabil 2009; 23:117-24.

43 Mikhailov VA. Results of treatment of the patients with second- to third-stage breast cancer by combination of low level laser therapy and surgery - ten-year experience. In: Longo L, Hofstetter AG, Pascu ML, Waidelich WR, editors. A window on the laser medicine world. Bellingham: SPIE; 1999; Vol. 4166. p. $40-42$.

44 Lenhard RE, Osteen RT, Gansler T. Clinical oncology. Atlanta (GA): The American Cancer Society; 2001

45 Renno ACM, McDonnell PA, Parizotto NA, Laakso EL. The effects of laser irradiation on osteoblast and osteosarcoma cell proliferation and differentiation in vitro. Photomed Laser Surg, 2007;25:275-80.

46 Powell K, Low P, McDonnell PA, Laakso EL, Ralph SJ. The effect of laser irradiation on proliferation of human breast carcinoma, melanoma, and immortalized mammary epithelial cells. Photomed Laser Surg 2010;28:115-23.

47 Ciais G, Namer M, Schneider M, Demard F, PourreauSchneider N, Martin PM, et al. Soft-laser therapy for prevention and treatment of mucositis induced cancer chemotherapy. Bull Cancer 1992;79:183-91.

48 Pourreau-Schneider N, Soudry M, Franquin JC, Zattara H, Martin PM, Ciais G, et al. Soft-Laser therapy for iatrogenic mucositis in cancer patients receiving high-dose fluorouracil: a preliminary report. J Nat Cancer Inst 1992;84:358-59.

49 Franquin JC, Tardieu C, Schubert M, Hamdi M, Cowen D. Phase II study of $\mathrm{He}-\mathrm{Ne}$ laser prevention in BMT conditioning induced oral mucositis. Cancer Res Weekly 1994 Jul: Gale document no. A15540724.

50 Schubert M, Franquin J, Niccoli-Filho W, Marcial F, Lloid M, Kelly J, et al. Effects of low-energy laser (LEL) on oral mucositis: a phase I/III pilot study. Cancer Res Weekly 1994 Jul: Gale document no. A15540720.

51 Barasch A, Peterson DE, Tamer JM, D'Ambrosio JA, Nuki K, Schubert MM, et al. Helium-neon laser effects on conditioninginduced oral mucositis in bone marrow transplantation patients. Cancer 1995;76:2550-56.

52 Cowen D, Tardieu C, Schubert M, Peterson D, Resbeut M, Faucher C, et al. Low energy helium-neon laser in the prevention of oral mucositis in patients undergoing bone marrow transplant: results of a double blind randomized trial. Int J Radiat Oncol Biol Phys 1997;38:697-703.

53 Bensadoun RJ, Franquin JC, Ciais G, Darcourt V, Schubert MM, Viot M, et al. Low-energy helium-neon laser in the prevention of radiation-induced mucositis - a multicentre phase III randomized study in patients with head and neck cancer. Support Care Cancer 1999;7:244-52.

54 Migliorati C, Massumoto C, de Paula Eduardo F, Muller KP, Carrieri T, Haypek $\mathrm{P}$, et al. Low-energy laser therapy in oral mucositis. J Oral Laser Applic 2001;1:97-101.

55 Wong SF, Wilder-Smith P. Pilot study of laser effects on oral mucositis in patients receiving chemotherapy. Cancer $\mathbf{J}$ 2002;8:247-54.

56 Nes AG, Posso MB. Patients with moderate chemotherapyinduced mucositis: pain therapy using low intensity lasers. Int Nurs Rev 2005;52:68-72.

57 Maiya GA, Sagar MS, Fernandes D. Effect of low level heliumneon $(\mathrm{He}-\mathrm{Ne})$ laser therapy in the prevention \& treatment of radiation induced mucositis in head \& neck cancer patients. Indian J Med Res 2006;124:399-402. 
58 Cruz LB, Ribeiro AS, Rech A, Rosa LG, Castro CG Jr, Brunetto AL. Influence of low-energy laser in the prevention of oral mucositis in children with cancer receiving chemotherapy. Pediatr Blood Cancer 2007;48:435-40.

59 Jaguar GC, Prado JD, Nishimoto IN, Pinheiro MC, de Castro DO Jr, da Cruz Perez DE, et al. Low-energy laser therapy for prevention of oral mucositis in hematopoietic stem cell transplantation. Oral Dis 2007;13:538-43.

60 Arora H, Pai KM, Maiya A, Vidyasagar MS, Rajeev A. Efficacy of $\mathrm{He}-\mathrm{Ne}$ laser in the prevention and treatment of radiotherapy-induced oral mucositis in oral cancer patients. Oral Surg Oral Med Oral Pathol Oral Radiol Endod 2008;105:180-86.

61 Fulop AM, Dhimmer S, Deluca JR, Johanson DD, Lenz RV, Patel KB, et al. A meta-analysis of the efficacy of phototherapy in tissue repair. Photomed Laser Surg 2009;27:695-702.

62 Werneck CE, Pinheiro AL, Pacheco MT, Soares CP, de Castro $\mathrm{JL}$. Laser light is capable of inducing proliferation of carcinoma cells in culture: a spectroscopic in vitro study. Photomed Laser Surg 2005;23:300-03.

63 Sabo J, Mirossay L, Horovcak L, Sarissky M, Mirossay A, Mojzis J. Effects of static magnetic field on human leukemic cell line HL-60. Bioelectrochemistry 2002;56:227-31.

64 Harris SR, Hugi MR, Olivotto IA, Levine M. Clinical practice guidelines for the care and treatment of breast cancer: 11 . Lymphedema. CMAJ 2001;164:191-99.
65 Hayashi S. Der Einfluss der ultraschalwellen und ultrakurtzwellen auf den maligen tumor. Jpn J Med Sci 1940;6:182.

66 Sicard-Rosenbaum L, Danoff JV, Guthrie JA, Eckhaus MA. Effects of energy-matched pulsed and continuous ultrasound on tumor growth in mice. Phys Ther 1998:78:271-77.

67 Watanabe Y, Aoi A, Horie S, Tomita N, Mori S, Morikawa Y, et al. Low-intensity ultrasound and microbubbles enhance the antitumor effect of cisplatin. Cancer Sci 2008;99:2525-31.

$68 \mathrm{Yu} \mathrm{T}$, Wang Z, Mason TJ. A review of research into the uses of low level ultrasound in cancer therapy. Ultrason Sonochem 2004;11:95-103.

69 Feng Y, Tian ZM, Wan MX, Zheng ZB Low intensity ultrasound-induced apoptosis in human gastric carcinoma cells. World J Gastroenterol 2008;14:4873-79.

70 Feril LB Jr, Kondo T. Biological effects of low intensity ultrasound: the mechanism involved, and its implications on therapy and on biosafety of ultrasound. J Radiat Res (Tokyo) 2004;45:479-89.

71 Vargas HI, Dooley WC, Gardner RA, Gonzalez KD, Venegas $\mathrm{R}$, Heywang-Kobrunner SH, et al. Focused microwave phased array thermotherapy for ablation of early-stage breast cancer: results of thermal dose escalation. Ann Surg Oncol 2004;11:139-46.

72 Santana-Blank L. Modulated low-energy near-infrared lasers and cancer: an invitation to discuss a new treatment approach. Lasers Surg Med 2003;32:1-2. 